[Vicino Oriente XVIII (2014), pp. 145-171]

\title{
LISTEN AND PROTECT: \\ RECONSIDERING THE GRINNING MASKS AFTER A RECENT FIND FROM MOTYA*
}

\author{
Adriano Orsingher - Sapienza University of Rome
}

"A mask tells us more than a face"

Oscar Wilde, Pen, Pencil and Poison: a Study in Green (1889)

\begin{abstract}
Le maschere occupano una posizione di rilievo all'interno degli studi sulla coroplastica fenicia e punica, testimoniando dapprima il reiterarsi di modelli ispirati al repertorio siro-palestinese, poi una rielaborazione autonoma di Cartagine, in seguito adottata e in parte modificata in alcune produzioni locali, infine il sopraggiungere di stilemi e iconografie legate alla tradizione greca. Il recente rinvenimento di un frammento di maschera punica a Mozia costituisce l'occasione per un riesame di alcuni temi connessi a questa classe, agevolando l'inquadramento della nuova attestazione.
\end{abstract}

Keywords: Phoenicians; Motya; Mediterranean; masks; Carthage

\section{IN THE SHADOW OF THE VINEYARD: THE FIND AND THE MISSING CONTEXT}

Motya is in many respects an ideal archaeological context as very few modern buildings cover the ancient city. It has remained undisturbed apart from agricultural activities, which - in some areas of the island - continue until today, sometimes resulting in unexpected discoveries.

During the spring of 2011, a fragmentary terracotta ${ }^{1}$ was found on the eastern edge of the vineyard bordering, to the west, the olive road $\left(37^{\circ} 52^{\prime} 10.7^{\prime \prime} \mathrm{N} 12^{\circ} 28^{\prime} 02.9^{\prime \prime} \mathrm{E}\right)$, about sixty meters from the southern fence of the Tophet (fig. 1). The position and the presence of a recent fracture suggest that this discovery was the result of spring ploughing. The original context, however, is indeterminable. The proximity of the Tophet is clearly suggestive, but a recent geophysical survey ${ }^{2}$ seems to indicate the presence - to the south of the sanctuary of several architectural structures, whose function, dating and possible relation to the nearby sacred area, only future archaeological investigations will be able to clarify.

* I am greatly indebted to Professor Lorenzo Nigro, Director of Rome "La Sapienza" Archaeological Expedition to Motya, for allowing me the publication of this fascinating find and for his advice and encouragement. I owe many thanks to Professors Maria Giulia Amadasi Guzzo, Piero Bartoloni, Anna Maria Gloria Capomacchia and Josephine Crawley Quinn for their helpful comments on earlier drafts of this paper. I gratefully acknowledge the kind help and assistance of Dr Alessandra Guari, author of the drawings in fig. 2. Figs. 3-4 are the Author's elaborations: the drawings in fig. 4 are stylized and not to scale, based on available photos and drawings. I would like to thank the following institutions and individuals for kindly providing me with illustrations, inventory numbers and bibliography references: The Trustees of the British Museum, $R M N$ Grand Palais (musée du Louvre), Dr J.H. Fernández (Museu Arqueològic d'Eivissa i Formentera), Dr Jordi Principal (Museu d'Arqueologia de Catalunya), Dr Pamela Toti (G. Whitaker Museum), Prof Raimondo Zucca (Università degli Studi di Sassari) and Prof Pier Giorgio Spanu (Università degli Studi di Sassari).

1 Inv. no. MO.11.0/a; that is Motya; followed by the year of the finding (2011), 0 corresponding to the humus and the letter referring to the chronological order among the finds.

2 Di Mauro et al. 2014. On the recent archaeological investigations in the Tophet of Motya, see: Nigro 2013. 
This paper aims to analyse the terracotta fragment ${ }^{3}$ (fig. 2), providing a typological and chronological framework within the very extensive Phoenician and Punic coroplastic production.

\section{THE PIERCED EAR: MOVING AMONG HEADS, BUSTS, PROTOMES AND MASKS}

In this fragmentary terracotta part of a right cheek and ear, characterized by the presence of two holes made on the lobe and the helix, is preserved. The presence of one or more holes on the ears ${ }^{4}$ (sometimes also on the nose ${ }^{5}$ ) - which could originally have contained a metal earring ${ }^{6}$ - was common to different types of votive terracottas, ${ }^{7}$ such as masks, protomes, ${ }^{8}$ busts $^{9}$ and heads. ${ }^{10}$

Despite the fragmentary conservation status, the manufacture of the back side (hollow and worked) and the morphology of the ear suggest that it is a mask. Among the various mask typologies, the only currently known on ${ }^{11}$ with these kinds of holes in the ears is the grinning type, to which this fragment can be thus attributed.

\section{APPROACHING THE MASKS: CONTEXTS, (RE)USES AND FUNCTIONS}

The function of the masks cannot be defined a priori, but must be clarified individually taking into account the context (usually industrial areas, dwelling quarters, sacred areas and tombs) and some morphological elements, such as the dimensions (full-size or over life-

3 MO.11.0/a (G. Whitaker Museum, inv. no. 8071), mask. Context: 3752'10.7"N 12²8'02.9"E, humus Material: clay. Manufacture technique: matrix moulded, hand-modelling and stick finishing. Description: right ear and cheek of a mask. Conservation status: fragmentary. Fabric colour: 2.5Y7/3 Pale Yellow, core 5YR6/8 Reddish Yellow. Production: non local (Carthage?). Ware: hard, porous, rough to the touch; inclusions: white limestone (size: small/large, frequency: high/rare) and quartz (size: small; frequency: high). Surface treatment: beige washing (5Y8/2 Pale Yellow) on both sides, coated with yellow paint (7.5YR7/8 Reddish Yellow) preserved only in a few spots. H. $7,0 \mathrm{~cm}$. D. $0,5 / 0,9 \mathrm{~cm}$. L. $4,8 \mathrm{~cm}$. Chronology: c. second half of the $6^{\text {th }}$ century BC.

4 This was a practice frequently attested in the Near East. At first, it was apparently limited to (male and female) divine figures, but, afterwards, it was extended to the royal and possibly, later on, to high ranking figures (such as dignitaries and knights).

5 Quillard 1987, 157-159.

6 Quillard 1987, 159-161, pl. XXXIV:1-2.

7 On the terminological issue, see: Fariselli 2011, 155, note 1. Considering the existence of common features, masks and protomes have often been analyzed together (Ciasca 1988; 1991, 6). Three main criteria usually distinguish them from one another: in protomes the representation also included the neck, while the apertures for the eyes (and the mouth) were missing (they could be painted or coated with precious materials) and the back side was flat. However, there were some hybrid specimens. Some protomes presented - sometimes simultaneously (Nigro 2004, 39, fig. 3) - intermediate features: the representation could be limited to the face (Acquaro - De Vita 2010, 108) and the back side could be hollow with through holes along the edge. In a terracotta (Acquaro - De Vita 2010, 109), classified as a mask in consideration of the apertures for eyes, the representation was extended to the neck.

8 Ciasca 1988,368 .

9 Bisi 1988, 334, 352

10 Ciasca 1988, 369

11 The morphology of a mask with pierced ear from Carthage is different (Acquaro - De Vita 2010, 109). 
size) and the profile, besides the presence/absence and the number and position of through holes along the edge. ${ }^{12}$

Since the first studies, ${ }^{13}$ their apotropaic value has been unanimously ${ }^{14}$ recognized, considering their presence both in dwellings and tombs ${ }^{15}$ (where the masks were often deposed next to the dead, close to or facing the entrance). ${ }^{16}$ This apotropaic function ${ }^{17}$ seems to be confirmed by the replica of some types as amulets ${ }^{18}$ (especially the negroid ${ }^{19}$ and silenic ${ }^{20}$ ones). Similarly, this value can also be recognized for the (divine) faces, figures and symbols carved or painted in the chamber tombs. ${ }^{2}$

The masks with one or more suspension holes on top were likely hung ${ }^{22}$ on the walls of houses or sanctuaries. ${ }^{23}$ Whereas, those under life-size and with several holes along the edge could be applied to any (wooden or other material) support, such as the head of statues. $^{24}$

Regarding the life-size clay masks, the issue of whether they could be worn during religious ceremonies has often been raised. This use, illustrated by several Cypriot terracottas, ${ }^{25}$ has often been denied ${ }^{26}$ taking into account some considerations: a) the presence of a single top hole (which presumes the suspension); b) the stiffness of the material; c) the depth ${ }^{27}$ and the manufacture of the inside (without an enlargement corresponding to the ears); d) the absence of nasal (and sometimes mouth) openings for

12 Among the most recurrent pattern, there were: one or two holes on top; one on top and two above the ear; one on top and two pairs above and below the ear; four on top; holes all around.

13 Taramelli 1915

14 Among the others, see: Moscati 1968, 132; Bénichou-Safar 1982, 267, note 219; Fariselli 2011, 165.

15 Recently (Fariselli 2011, 165), the issue has been raised that the deposition of masks in tombs was the final destination instead of the primary function, namely the re-use of an insignia previously employed in daily life (Lancellotti 2006, 63). Although plausible, this hypothesis may be difficult to prove without use-alteration traces, fractures, ancient restorations and morphological features incompatible with the tomb architecture (such as through holes for a mask placed on the floor) or when the context clearly testified an heirloom value.

16 Cintas 1946, 48; Bénichou-Safar 1982, 313

17 Bénichou-Safar $(1982,275)$ did not rule out their use in rituals preceding the deposition of the dead. This hypothesis has been taken up and extended in: López-Bertran - Garcia-Ventura 2008, 30.

18 Moscati 1968, 257-258; Culican 1976; Del Vais - Fariselli 2012, 75. The grinning type was also reproduced in some Carthaginian cretulae (Morstadt 2010, 209, fig. 14).

19 Bartoloni 1973, 184-185, 195, pl. LIX:50; Moscati 1987, 125, pl. XXXII:2.

20 Moscati 1983

21 A few examples are in: Garbini 1968, 323-324; Culican 1975-1976, 73. For a different interpretation of a recent case, see: Bernardini 2005, 75-76, proposing to consider the figure carved in a chamber tomb of Sulky as the representation of the dead.

22 For a wide mask from Akhziv (Culican 1975-1976, fig. 16) attachment to a wall could be presumed.

23 This is the case of the mask (with three holes on top) found close to the entrance of the Chapelle Carton (Carton 1929, 13, no. 20). See also the considerations in: Smith 2009, 120-121.

24 Ciasca 1992, 149.

25 Karageorghis 2006, 159-161, figs. 154-155.

26 Campanella 2009, 530.

27 Gauckler 1915, pl. CXCIX:1-2. Considering the frequent absence of the masks' profile drawings, the various functional hypotheses cannot be verified - without an autoptic analysis - solely through frontal images. 
easy breathing. ${ }^{28}$ Moreover, it has been suggested that the clay masks were not worn and they reproduced perishable $e^{29}$ prototypes made of leather, wood ${ }^{30}$ and cloth. ${ }^{31}$ This thesis, however, would not explain the presence of the eye-holes and why - if the masks were just meant to be hung or attached to simulacra - protomes were not used.

\section{A VIEW ON THE GRIMACING MASKS}

The production of face masks in the Near East dates back to at least the Pre-Pottery Neolithic B. ${ }^{32}$ However, the first specimens with features next to the $1^{\text {st }}$ millennium BC masks appeared during the Late Bronze Age. ${ }^{33}$ Currently, the earliest masks found in Phoenicia during the Iron Age are the specimen from Khaldeh, whose chronology is uncertain, ${ }^{34}$ and the fragment from Tyre stratum X-1, dating back to the mid- $9^{\text {th }}$ century $\mathrm{BC}{ }^{35}$ The production of masks continued in the West, ${ }^{36}$ probably ending during the $2^{\text {nd }}$ century $\mathrm{BC}$, when the models relevant to other traditions - which had already been accepted in the Punic repertoire (as evidenced by the silenic type) - prevailed.

Among the numerous types composing the repertoire of Phoenician and Punic masks, which were classified by Pierre Cintas, then reworked by Colette Picard and later sketched by Ephraim Stern $^{37}$ (Tab. 1), one of the most well-known has been defined as grinning because of the mouth shape.

The grinning masks portray male hairless characters with some defined features: the moon crescent-shaped eyes, the engraved or impressed furrows on the forehead and cheekbones, the open mouth baring teeth. On the forehead engraved or impressed symbols, sometimes repeated also on the cheekbones and chin, could be applied. These

28 These features could be a real obstacle only if we assume a continuous and long lasting use during the rites. It was also observed (Kletter 2007, 194) that the masks could be kept in one hand and used away from the face. According to this hypothesis, also the under life-size masks could be employed.

29 Based on a bronze mask from a private collection in Budapest, G. Garbini (1968, 325-326, pl. III) suggested also metallic prototypes. To my knowledge, there is no further information on this specimen and its authenticity - considering the similarity with the mask from San Sperate - is highly dubious.

30 The hypothesis of wooden prototypes seems particularly persuasive for the negroid masks; see in particular a specimen from Carthage: Picard 1965-1966, fig. 2.

31 Picard 1965-1966, 89; Karageorghis 1996.

32 O'Neill 1986, 46, fig. 22; 48-49. See also the recent exhibition: "Face to Face: The Oldest Masks in the World", The Israel Museum, Temporary Exhibition Gallery, Samuel and Saidye Bronfman, Archaeology Wing, 11 March - 11 September 2014.

33 Glenn Markoe (1990, 14-16), based on stylistic considerations, in the Cypriot production of the Late Bronze Age, the prototypes of the earliest Phoenician specimens recognized. See also: Fariselli 2014.

34 The context of this mask - an infant burial dating back to the end of the Iron Age I/early Iron Age II (Culican 1975-1976, 55, no. 3 fig. 11) - is still unpublished.

35 Bikai 1978, 67-68.

36 Currently, in the West, the earliest masks - fragmentary and therefore difficult to classify typologically - are an item from Morro de Mezquitilla (Horn 2005, 1409, fig. 4), usually dated to the $8^{\text {th }} / 7^{\text {th }}$ centuries BC, and a specimen (Niemeyer 2007, 763, no. 6143) from phase IIIA of Carthage (c. 700-675 BC).

37 Considering - at least - the terminological issues (such as the distinction between masks and protomes) and the new iconographies testified by recent discoveries, both these typologies should be updated. 
characteristics changed or fell out of use over time, but - albeit singly - allow us to recognize the specimens belonging to this type. ${ }^{38}$

\begin{tabular}{|c|c|c|c|c|c|c|c|c|c|c|}
\hline \multicolumn{2}{|c|}{ Cintas 1946} & \multicolumn{6}{|c|}{ Picard 1965-1966 } & \multicolumn{3}{|c|}{ Stern 1976} \\
\hline \multirow{5}{*}{$\begin{array}{l}\text { grimacing } \\
\text { masks }\end{array}$} & I & \multirow{4}{*}{ I } & \multirow{4}{*}{$\begin{array}{c}\text { demonic } \\
\text { masks }\end{array}$} & \multirow{3}{*}{ A) } & \multirow{3}{*}{ grotesque } & a) & negroid & \multirow{4}{*}{$\begin{array}{l}1 \mathrm{st} \\
\text { group }\end{array}$} & \multirow{4}{*}{\multicolumn{2}{|c|}{ grotesque family }} \\
\hline & II & & & & & \multirow{2}{*}{ b) } & \multirow{2}{*}{ grinning } & & & \\
\hline & III & & & & & & & & & \\
\hline & $\mathrm{V}$ & & & B) & \multicolumn{3}{|l|}{ satirical } & & & \\
\hline & IV & II & \multicolumn{5}{|c|}{ male protomes-masks } & & & \\
\hline \multirow{4}{*}{ protomes } & Egyptian style & \multirow{4}{*}{ III } & \multirow{4}{*}{$\begin{array}{l}\text { female } \\
\text { protomes- } \\
\text { masks }\end{array}$} & A) & \multicolumn{3}{|c|}{ Egyptisant style } & \multirow{4}{*}{$\begin{array}{l}\text { 2nd } \\
\text { group }\end{array}$} & & \multirow{2}{*}{$\begin{array}{l}\text { Phoenicio-Egyptian } \\
\text { Style }\end{array}$} \\
\hline & intermediate & & & D) & \multirow{2}{*}{\multicolumn{3}{|c|}{ Greek-Phoenician style }} & & protomes & \\
\hline & style & & & & & & & & & Phonici Croct Stylo \\
\hline & Greek style & & & C) & \multicolumn{3}{|c|}{ Rhodium style } & & & Phoenicio-Greek Style \\
\hline
\end{tabular}

Tab. 1 - Correspondence table between the various classifications.

Some of these traits ${ }^{39}$ can be recognized in masks found in Cyprus and the Levant, even if the overall iconography was different. Therefore, this type seems to be a Western (likely Carthaginian) autonomous reworking, which made use of elements already present (although separately) in the Levantine coroplastic tradition.

\subsection{A chronological analysis: the key-contexts}

The chronological framework of this type is hindered by several factors: a) most of the intact specimens were found - during the $19^{\text {th }}$ and early $20^{\text {th }}$ century - in tombs which grave goods are usually unknown; b) the long-term use of some graves and c) the possible presence of heirlooms. Considering their relevance to the outlining of chronological anchors, some contexts have been identified.

\subsubsection{The dwelling quarter of Carthage}

An important contribution to the framework of this class has been offered by recent discoveries at Carthage. ${ }^{40}$ Based on such small fragments, the production of masks started at least around the mid- $7^{\text {th }}$ century BC. ${ }^{41}$

38 The typological attribution of the fragmentary mask found in the so-called Luogo di Arsione at Motya is uncertain (Ciasca 1991, 30). Here, we prefer to exclude it from the catalogue of the grinning-type specimens.

39 These are: the furrows on the forehead of two masks from Tel Dor (Stern 2010, figs. 29:4, 6); the engraved lines on the cheekbones of a mask from Kourion (Ciasca 1988, 357) and a fragment of Amrit (Culican 19751976, 57, no. 5, fig. 20); the wrinkles of a specimen from Akhziv (Culican 1975-1976, 57, no. 4, fig. 12=Dayagi-Mendels 2002, fig. 7.23); one (Culican 1975-1976, 55, no. 3, fig. 11; 57, no. 6, fig. 17; 64, fig. 18, see also: Gjerstad et alii 1935, pl. CCXXII:1-2) or two applied disks (Vermeule ed. 1972, fig. 30), the plant motif engraved on the forehead of a Tel Dor specimen (Stern 2010, fig. 29:4), the apparently grinning mouth of a fragment from Tel Beersheba (Kletter 2007, 195, fig. 5) and another specimen from Tel Dor (Stern 2010, fig. 29:1).

$40 \quad$ Niemeyer 2007, 762-763. 


\subsubsection{Gauckler's tomb 30 of Carthage}

Besides the specimens from the dwelling quarter, the earliest context of the North African metropolis is tomb 30 of P. Gauckler's excavations, which - according to a recent analysis by R. Zucca ${ }^{42}$ - can be dated between the late $7^{\text {th }}$ and the early $6^{\text {th }}$ century BC.

\subsubsection{The middle favissa in the Tophet of Motya}

As has been pointed out recently ${ }^{43}$ the central favissa in the Tophet of Motya is a complicated context. This votive deposit - dug in the stratum V (c. 625-550 BC) - included ten terracottas: ${ }^{44}$ a grinning mask, a Selinus female protome, six Egyptianising female busts, a plaque with a female head and a female protome with klaft. According to its excavator, the favissa should be considered a uniform deposit, despite the doubts raised by the grinning mask's peculiar position: it was discovered at the bottom of the favissa, above the mouth of a stratum VI cooking pot. ${ }^{45}$ Among the terracottas, the Selinus import attributed on the basis of the comparisons ${ }^{46}$ to the decades c. $510-480 \mathrm{BC}-$ is the terminus post quem for the favissa dating and a reference point for the chronology of the other specimens. Therefore, all these terracottas dated back to approximately between the second half of the $6^{\text {th }}$ and the first decades of the $5^{\text {th }}$ century BC. ${ }^{47}$

\subsubsection{Tomb 7 of Tharros}

Another (small) reference point can be recognized in Tomb 7 of the excavations carried out by Gaetano Cara at Tharros: ${ }^{48}$ in this burial kit, a few materials dating back to the late $5^{\text {th }}$ century $\mathrm{BC}^{49}$ were discovered.

\subsubsection{Hypogeum 22 of Puig des Molins}

Among the masks from Ibiza, ${ }^{50}$ the only datable specimen comes from Hypogeum $22^{51}$ investigated by Carlos Román Ferrer ${ }^{52}$ in the necropolis of Puig des Molins. In this recently re-examined tomb, ${ }^{53}$ an Attic lamp, Howland type 22B (c. 475-410 BC), was retrieved.

41 According to their chronological order, these contexts are strata IVb (c. 645-550 BC), IVc (c. 600-550 BC); VIa (c. 480-425 BC). The typological attribution of the sherd (Niemeyer 2007, 763, no. 6143, pl. 49) from stratum IIIa (c. 700-675 BC) is uncertain.

42 Zucca 2012, 477.

43 Orsingher 2013, 693, note 4 .

44 Ciasca 1964, 61-68, pls. XLIV-XLVIII, L-LIII; Ciasca - Toti 1994, 9-12.

45 Considering the chronology of stratum VI (c. 675-625 BC, for the stratigraphy and chronology of the Tophet, see Nigro 2013, tab. 1), we can exclude the hypothesis of an original relation between the deposition and the mask: otherwise, the terracotta would be one century older than the other specimens of this type. In any case, the special care demonstrated in the placement of the mask still has to be explained: above the urn's mouth and with the face turned upwards.

46 Wiederkehr Schuler 2004, 80, 202, note 14, pl. 57.

47 Based on the above historical considerations, the deposition of these votive terracottas, which were probably part of the ritual kit, could be included among the actions taking place in Motya after the battle of Himera in $480 \mathrm{BC}$. Their displacement may testimony a cultural change, such as the exit of Motya from the orbit of the North African metropolis (in fact nine-tenths of the specimens were Carthaginian imports or types).

48 Barnett - Mendleson eds. 1987, 152, 7/16, pl. 30.

49 Zucca 2012, 476

50 Almagro Gorbea 1980, 236-239, pls. CLXVIII-CLXIX. 
XVIII (2014) Listen and protect: reconsidering the grinning masks after a recent find from Motya

\subsubsection{The "Chapelle Carton" in Carthage}

Finally, a chronological anchor is represented by the mask ${ }^{54}$ recovered at Carthage by L. Carton in the destruction layer of a shrine located $500 \mathrm{~m}$ west of the Tophet. The construction of this small temple has been assigned to the end of the $3^{\text {rd }}$ century $\mathrm{BC},{ }^{55}$ while its destruction could be the outcome of the $3^{\text {rd }}$ Punic War. Therefore, the dating of this mask falls within these two extremes (c. 225-146 BC).

\subsection{Looking East to Look West: a Carthaginian model and its transformation}

These contexts allow us to put forward a broad definition of the development of the grinning type masks (fig. 3). Currently, its elaboration does not seem to forerun the mid- $7^{\text {th }}$ century BC. The mask from Tomb 30 in Carthage (fig. 3:1) represents the earliest type (I). The elliptical shape recalls some specimens from Akhziv, ${ }^{56}$ while other elements recur between the fragments from the dwellings of Carthage: the open mouth baring teeth ${ }^{57}$ the furrows on the forehead, near the eyebrow arches ${ }^{58}$ and - sometimes - separated by two or more applied discs, ${ }^{59}$ which were a feature already known in Cyprus and the Levant. Possibly, four masks without context data - two from Carthage ${ }^{60}$ (fig. 3:2-3) and two from Tharros $^{61}$ (fig. 3:4-5) - also belong to this stage, which - according to the Carthaginians specimens - dates back to c. 650-550 BC.

The next stage (II) is testified by several specimens: two from Carthage (figs. 3:10-11), one from the Tophet of Motya (fig. 3:6), one from Tharros (fig. 3:7), one from San Sperate $^{62}$ (fig. 3:8), one from Sinis di San Vero Milis ${ }^{63}$ (fig. 3:9) and one from Puig des

Almagro Gorbea 1980, 238, no. 3904, pl. CLXVIII:2.

Román Ferrer 1923, 13, 19, pl. V:c.

Fernández 1992, 107, 125-126; fig. 64, pl. LX.

Carton 1929, 13, no. 20, 53, pl. I:1.

Mancini 2012.

Dayagi-Mendels 2002, 158-159, figs. 7.22-7.23.

Niemeyer 2007, fig. 417:6136.

Niemeyer 2007, fig. 417:6137, 6139.

Niemeyer 2007, fig. 417:6139. Currently, this feature is known only in Cyprus.

60 R. Zucca $(2012,477)$ suggested a chronology between the mid- $7^{\text {th }}$ and early $6^{\text {th }}$ century BC for the mask (fig. $3: 3)$ retrieved in tomb 1 during the excavations of P. Gauckler $(1915,1)$. Previously, C. Picard (1965-1966, 12, no. 3), concluded on the basis of the excavator's observation (Gauckler 1915, XVII) that this tomb should be included among the earliest ones and proposed a dating in the first quarter of the $7^{\text {th }}$ century BC. Because there are no pictures and drawings of the burial vessels, we prefer to consider the grave as undatable. Equally, Hélène Bénichou-Safar $(1982,419)$ excluded it from the list of dated tombs.

61 These two examples have already been compared on a stylistic bases, first by Sabatino Moscati (1987, 99 $100)$ and recently by R. Zucca $(2012,477)$, to the Tomb 30 specimen. The latter scholar also included in the earliest group the mask in the National Museum of Cagliari (fig. 3:14), which is here considered relevant to a later stage. The two masks from Tharros differ from the Carthaginian examples in their proportions and in their features, perhaps indicating their posteriority. Especially the mask in the Antiquarium Arbonense (fig. 3:5) - with the upper and lower teeth close to each other and circular holes at the sides - resembles the later types. Two circular impressions, which may indicate the original presence of two applied circular discs, on the cheekbones of the specimen in the museum of Cagliari (fig. 3:4) seem recognizable.

62 The context of the mask from San Sperate is unknown. The tombs so far investigated in this necropolis date from the $5^{\text {th }}$ century BC (Bartoloni 1967; Tronchetti 1986, 101; Ugas 1993, 58), which could be a terminus ante quem for the dating of the mask. 
Molins (fig. 3:11). ${ }^{64}$ Data provided by such contexts suggest a chronological framework between the second half of the $6^{\text {th }}$ and the first decades of the $5^{\text {th }}$ century BC. During this phase, the grinning mask lost its humanised traits, acquiring more stylized characteristics: the eyes turned into half-moons, the grooves engraved on the forehead were placed higher and the absence of the applied discs or - more often - their replacement by impressed or engraved vertical bands or other applied decorations, rarely repeated also on the chin. The ears became over-sized, sometimes with one hole on the lobe, which might also be repeated on the helix and nose.

At this stage, two groups can be distinguished: in the former, composed by the masks of Motya and Tharros, the upper and lower teeth were distant from each other and the ears well-proportioned; in the latter, formed by some masks from Carthage, the upper and lower teeth were close to each other and the ears were over-sized. The specimen from San Sperate and possibly the one from Sinis di San Vero Milis, both with the distant upper and lower teeth and giant ears, testify intermediate characteristics. The close upper and lower teeth, a feature existing also in the earliest example from Puig des Molins ${ }^{65}$ and in the later group, may be a marker of posteriority.

A following stage (III) - to be dated to the $5^{\text {th }}$ century $\mathrm{BC}$, perhaps until the first decades of the $4^{\text {th }}$ century $\mathrm{BC}-$ is recognizable through the masks of Ibiza, ${ }^{66}$ in which the eyes became enlarged half-rounds and the furrows on the forehead and cheeks were impressed (fig. 3:13-14). Furthermore, the ears were again proportionate, while two circular holes were cut on the sides of the teeth. To this group probably belongs a mask from Tharros, which is likely earlier than Ebusitan specimens (fig. 3:12). This suggestion is based on some features: the half-round mouth, the close upper and lower teeth, with the two circular holes at the sides; the high position of the grooves engraved on the forehead and the impressed eyes sockets.

The last stage (IV) corresponds to the mask retrieved in the Chapelle Carton (fig. 3:15), in which the eyes maintained a half-moon shape, the grooves on the forehead and cheeks were engraved, and the applied discs reappeared, repeating, in their number and position, the pattern of the earliest masks. ${ }^{67}$ The headband tied around the forehead and the large and semicircular mouth, without teeth, were the main features deriving from the Hellenistic tradition. $^{68}$

63 Spanu - Zucca 2011, 53, note 289, fig. 29:right.

64 The ear from Motya can also be included in this group. Its dimensions make it similar to the two specimens from Carthage and San Sperate. In the Motyan fragment, the clay (visible only through a recent fracture) seems - according to a macroscopic examination - similar to the fabric type CAR-REG-C-3 FACEM. http://facem.at/car-reg-c-3 (June 2, 2014).

65 In this mask the holes on the sides of the teeth are lacking. Maybe, it could depend on an oversight, as it would suggest coarse manufacture, especially evident in the irregular and asymmetrical edge.

66 Almagro Gorbea 1980, pls. CLXVIII:1-2, 4; CLXIX.

67 The reference to an archaic pattern during the Hellenistic period testifies the will to take inspiration from the Near Eastern roots, as occurred for the statue of the enthroned goddess from Soluntum (Chiarenza 2013). Following Diodorus (XX, 14, 1-3), at Carthage, during these stages, there would be - as a reaction to the danger represented by Agathocles - the restoration of ancient religious traditions (Xella 1999-2000, 363).

68 For the handkerchief (in a female character), see: Bernabò Brea 1981, 229-230, no. 41, fig. 393, pl. XLI:1-2, while for the mouth: Bernabò Brea 1981, 121, figs. 196-197. 
XVIII (2014) Listen and protect: reconsidering the grinning masks after a recent find from Motya

Currently, the phase I type has been discovered only at Carthage and Tharros, where it probably arrived at an advanced stage and local production soon began. During phase II, the distribution area included other settlements in the central Mediterranean (Motya, San Sperate, Sinis di San Vero Milis and Ibiza): all these centres were within the economic and political orbit of the North African metropolis. The lost specimen from Sinis di San Vero Milis confirms the active role of Tharros in the inland distribution of Carthaginian imports. Likewise, the mask from San Sperate might imply a similar role for Cagliari. Afterwards, phase III showed a decline in production, which apparently was still active only in Ibiza and Tharros. The only mask belonging to the final stage brings us back to Carthage and to some features of the earliest specimens: it could be evidence of an archaizing taste, perhaps tied to the recurrence - during the Hellenistic Age - of earliest religious traditions practiced in the Phoenician West.

\section{4. “UNMASKING THE FACE": SEARCH FOR AN IDENTITY}

The identity of the male character represented in the grinning masks remains difficult to clarify. Several suggestions have been made, ${ }^{69}$ but these investigations were not concerned with all the features characterizing (not always simultaneously) this iconography, such as the furrows on the forehead and cheeks, the smile, the applied, engraved or stamped symbols on the forehead, the cheeks and the chin and the over-sized ears. Hereinafter, their analytical analysis is undertaken.

69 The hypothesis of a link between the iconography of Huwawa/Humbaba and the grinning masks has been suggested by R. Barnett $(1960,147)$ and subsequently resumed by other scholars (such as Culican 1975-1976, 67, and recently Stern 2010, 25). A disc-shaped plaque from Sippar (c. 1800-1600 BC) in the British Museum (Smith 1924) is the only reliable iconography of this deity/demon (i.e. based on an inscription). The characteristic form of the face - formed by one continuous line of clay - is explained by the omen written on the back that begins: «If the entrails [resemble] the face of Humbaba, it is the omen of Sargon». Since the publication of this plaque, many iconographies have been attributed to Huwawa/Humbaba. We can distinguish two groups: a) the disk-shaped plaques with the image of a face, that is an iconography rarely replicated on masks and architectural elements; b) the beheading scene of a male character (usually) between two heroes. This subject was reproduced also on plaques and seals, then on reliefs, ivories and bowls. Despite the variations over time of these iconographies, the figure identified with Huwawa was characterized by the presence of (long) hair and a curled beard. The only common feature between the Punic masks and the Huwawa iconography is the sneer, recurring however only in the first group. The second iconographic scheme is documented also during the $1^{\text {st }}$ millennium BC in the Levant, as evidenced by a North Syrian ivory and two bowls - possibly Phoenician products - found at Nimrud (Lambert 1987, to which must be added the essays in Steymans ed. 2010). Instead, the disk-shaped plaques do not seem attested outside of Mesopotamia and after the $2^{\text {nd }}$ millennium BC (Moorey 2005, 94-95, no. 92). Therefore, the hypothesis of the influence of Huwawa on the Punic masks is limited to the grimace. However, this feature - which has yet to be unanimously interpreted: grin, smile or something else? - is also known in masks belonging to very distant cultural and chronological contexts (Rose 2006). 


\subsection{The furrows and the smile}

Horizontal/wavy (engraved or impressed) grooves were located on the forehead and cheekbones. P. Cintas interpreted them as wrinkles, recognizing these masks as representations of elderly people. ${ }^{70}$

Despite other proposals, ${ }^{71}$ this hypothesis remains the most credible explanation, especially looking at some details in the earliest masks (characterized by naturalistic traits): the crow's feet around the eyes, ${ }^{72}$ the wrinkle undulations on the forehead and cheekbones, ${ }^{73}$ all features - according to recent medical studies ${ }^{74}$ - of adult individuals.

The other characteristic is the pronounced smile, what Paul Ekman in his studies of emotions and their relation to facial expressions (which are universal and related to the muscles of the face) defined as a "broad enjoyment smile". ${ }^{75}$ Some wrinkles of expression such as the pushed up cheeks, the gathered skin under the eyes, the narrowed eye aperture and even the crow's feet wrinkles - can be traced back to this. ${ }^{76}$

\subsection{The symbols}

The iconological analysis of the symbols on the grinning masks raises some issues: 1) their identification (sometimes different readings of the same motif have been suggested ${ }^{77}$ ); 2) their meaning or, at least, their correlation to a certain sphere (e.g. uranian, chthonic, etc.) or to a specific god (the same symbol/animal can be associated with a range of deities and demons); 3) the ideological value of a symbol may change and even diminish over time (some of these motifs were imprinted on the rim of several basins during the $4^{\text {th }}-2^{\text {nd }}$ centuries $\mathrm{BC}^{78}$ and - apparently - many signs became fillers in the stelae from Tophet during the Hellenistic and Roman periods). Furthermore, it has been suggested (but cannot currently be demonstrated) that these symbols could be copies of paintings, tattoos ${ }^{79}$ or jewellery. ${ }^{80}$

In the repertoire of symbols applied to the masks (fig. 4) several motifs, such as the simple disc, the crossed disc, the lion's-head protome, lotus flowers, rosettes, the so-called apexed triangle and the ear, are recognizable. ${ }^{81}$

70 Cintas 1946, 49

71 Recently (Del Vais - Fariselli 2012, 77), these signs have been dubiously related to a biblical passage, identifying them with self-inflicted wounds during trance-like states.

72 Gauckler 1915, pl. CXCIX:2. A (colour and high resolution) photo of this detail is available on the web: http://terraeantiqvae.com/m/blogpost?id=2043782:BlogPost:224742 (July 20th 2014). Otherwise, the crow's feet could be related to the smile expression.

73 The furrows on the cheekbones were naturalistic (following the curve of the cheeks) only in the earliest specimens, as in the one from Carthage (fig. 3:2), very shortly (already during phase I) becoming stylized.

74 Hatzis 2004, 202-203, figs. 3-6.

75 Ekman 2003, 204-208.

76 The smile issue reminds the risus sardonicus, on this topic, see: Ribichini 2003.

77 Facenna 1996, 704, note 40.

78 Campanella 2008, 144-147.

79 This hypothesis has been put forward several times (Cintas 1946, 37; Fariselli 2011, 166). About tattooing practices in the Near East, see: Huehnergard - Liebowitz 2013, 69-73, where it has been considered a custom reserved for slaves. Therefore, it is not applicable to this instance.

80 Ciasca 1991, 39, 49. This would be jewelry such as: Poinssot - Lantier 1926.

81 For an analysis, see: Facenna 1996. 
XVIII (2014) Listen and protect: reconsidering the grinning masks after a recent find from Motya

In the earliest group of masks, there were only two types. The most common one, apparently the first, was the applied disc (sometimes mistakenly called wart ${ }^{82}$ ): two discs were vertically aligned in the mid-forehead (fig. 4:1-4), occasionally adding two more, one on each cheekbone (fig. 4:1-2). In the specimen from the Antiquarium Arbonense, there were four $\operatorname{discs}^{83}$ on the forehead (fig. 4:5), as many as the crossed discs (sometimes considered rosettes) engraved on both sides of the forehead and the jaw.

The disc can be considered as an astral symbol. ${ }^{84}$ This interpretation is based mostly on the analysis of two negroid masks, ${ }^{85}$ where one disc was surmounted by a crescent. ${ }^{86}$ The subsequent identification of this disc with a particular heavenly body - the most common ones were the sun, the (full or crescent) moon and a star (most likely Venus) - remains uncertain, as well as determining whether different stylized astral symbols or the same ones repeated ${ }^{87}$ were represented when they recur. Similarly, the crossed disc ${ }^{88}$ could be considered an astral symbol, such as the sun. ${ }^{89}$

Later, the iconographic repertoire was renewed. Currently, it seems a radical change (whose causes remain undetermined) rather than a gradual one. Certain new symbols - the lotus flower ${ }^{90}$ (fig. 4:8,13), the ear ${ }^{91}$ (fig. 4:12) and, obviously, the so-called Sign of Tanit ${ }^{92}$ (fig. 4:9) - are often connected to goddesses, fitting, as plant motifs, the fecundity theme. The case of the lion's head is uncertain: this feline, in fact, was associated with different deities. ${ }^{93}$ Moreover, several doubts ${ }^{94}$ were raised about the identification of another symbol

82 Cintas 1946,37

83 On the forehead of a fragmentary specimen discovered at Carthage (Niemeyer 2007, fig. 417:6139), there were - at least - three applied disks.

84 Picard 1976, 79-83.

85 Picard 1965-1966, figs. 1-2.

86 In a late stele (c. $4^{\text {th }} / 3^{\text {rd }}$ century BC), there were three disks arranged in a triangular shape: the lower one was surmounted by a crescent moon (Picard 1978, 21, pl. XV:1).

87 The repetition of astral symbols - already observed in the stelae of Motya (Del Vais 1993, 59) - could allude, as it has been suggested for ancient Mesopotamia (in this regard, see: Pizzimenti 2014, 152, with an extensive bibliography), to the main positions of the same heavenly body at different times of the day (or year?). Even the position of the disc on the cheekbone still needs to be clarified.

88 This is the symbol of Hadad/Baal since $2^{\text {nd }}$ millennium BC, with several renewed attestations in the Levant (e.g. a statue and a standing stone from the Orthostats Temple at Hazor: Yadin et al. 1961, pls. CCCXXIV CCCXXV, CCCCXXXI:1; see also: Ben-Tor 2006, 8, no. 16). For a recent analysis of the specimens, see: Hvidiberg-Hansen 2007, 223-224. Sometimes, certain symbols (such as the apexed triangle, see: Fariselli 2012,543 ) have been associated with alphabetic signs. The crossed disc apparently corresponds to the letter Țêt (ante $6^{\text {th }}$ century BC).

89 Pizzimenti 2014, fig. 1:b.

90 In this regard, see: Orsingher 2007, 119, notes 22, 25.

91 Nigro 2004-2005. See also: Picard 1978, 54-55.

92 Fantar 1996. The earliest examples of this symbol can be dated to the third quarter of the $6^{\text {th }}$ century BC, corresponding to the end of the second phase in the Tophet of Carthage (Bénichou-Safar 2004, 69, note 423).

93 Black - Green 1992, 40; Cornelius 1994, 195-196. For some lioness's heads, a special relationship with Astarte has been proposed in: Gubel 1985.

94 Furthermore, one symbol - variously interpreted - on the mask from San Sperate (fig. 3:8) is not recognizable (Facenna 1996, 704, note 40). 
as an apexed triangle or multiple cross $^{95}$ (fig. 4:9-11). The rosette (fig. 4:8, 13-14) is usually interpreted as an astral symbol, as it seems confirmed by its presence below a crescent moon in the stelae from the Tophet of Carthage. ${ }^{96}$ Possibly, the rosette, in this case and, perhaps, also when it is repeated three times, may have replaced other astral signs, ${ }^{97}$ a phenomenon already observed in Neo-Assyrian art. ${ }^{98}$

\subsection{The ears}

In masks belonging to phase II, the ears were over-sized and protruding. This emphasis is particularly evident in four specimens (no. 8-11), all likely Carthaginian products, to which the fragment here examined can probably be added. An analogy can be postulated with the ear stelae of the New Kingdom, ${ }^{99}$ a reference to the God's (hoped?) skill to listen to (and thus to accept) the worshipper's requests.

\section{A (CARTHAGINIAN) PORTRAit OF A GOD?}

The iconography here examined seems to be a Carthaginian creation, elaborated at least around the mid- $7^{\text {th }}$ century $\mathrm{BC}$, mostly reusing features already known in the iconographic repertoire of the Syro-Palestinian coast and Cyprus (the wrinkles, the pair of discs on the forehead, perhaps even the grimace). The figure represented is a male character, probably an old man (if the interpretation of the furrows on the forehead and cheekbones is correct), whose main feature is a wide smile, which seems to testify his benevolent character. The pair of discs on the forehead - likely referring to an astral connection - seems to be a divine attribute. They are testified in distant contexts, ${ }^{100}$ as well as in some bearded male protomes and masks: ${ }^{101}$ an iconography frequently used, since the $2^{\text {nd }}$ millennium $\mathrm{BC}$, for several deities (Reshef, the various Baal-named deities and Melqart), ${ }^{102}$ usually recognizable through the different elements held in their hands.

During the $6^{\text {th }}$ century $\mathrm{BC}$, the iconography became stylized: the appearance of plant motifs (possibly referring to the fertility theme and usually connected to goddesses, such as Astarte and Tinnit ${ }^{103}$ ), along with or as an alternative to new astral symbols, was observed. In some specimens the ears were oversized, perhaps suggesting the skill to listen to

95 The comparison, suggested by H. Sader (2005, 67-68), between the apexed triangle and the incised marks on the mask from Bou Minjel has been rejected by A.C. Fariselli (2012, 543, note 40), who recently reviewed this symbol, proposing instead to consider these signs as juxtaposed cruciform motifs. The problem remains open to perhaps even other solutions (double triangle? taw?).

96 Picard 1976, pl. VIII:10; 1978, pl. XVI:2.

97 Picard 1978, 5-6, 86-89.

98 Black - Green 1992, 156-157. In Neo-Assyrian art, it has been considered a symbol connected to Ishtar.

99 Luiselli 2013, 24-25, with extensive bibliography. The ears depicted in these stelae are interpreted as the iconographic translation of the divine epithet "he who hears prayers", whereas the large number of ears possibly reflects the worshipper's desire to increase the god's capacity to hear. Otherwise, given their continued growth (Niemitz - Nibbrig - Zacher 2007), the over-sized ears could be considered alternatively as a sign of aging.

100 Facenna 1996, 697, 701. See, also, the concluding remarks in: Garbini 1996.

101 Facenna 1996, 703, note 33.

102 Bonnet 1988, 77-90; Lipiński 1996.

103 The relation between these two gods has long been debated, see: Lancellotti 2010, 23-29. 
worshipper's requests. During the final decades of the $3^{\text {rd }}$ century $\mathrm{BC}$, the archaic iconography of this character was resumed. In fact, according to classical sources, during these phases the Carthaginians referred to the earliest traditions of the North African metropolis. The recovery of this iconography could imply a primary role of the represented character, which - based on the contexts (sacred areas, dwellings and tombs) - had to be widespread in all areas of daily life.

Currently, the sacred contexts - such as the Tophets (of Motya and, possibly, of Tharros) and the Chapelle Carton - permit the broad outline (if not the identify) of this figure. In the Tophets, the inscriptions give the leading role to Baal Hammon, which was accompanied (since the $5^{\text {th }}$ century BC) by Tinnit ${ }^{104}$ and exceptionally (from the $4^{\text {th }}$ century $\mathrm{BC}$ ) by other deities, testifying perhaps cases of single or collective devotion. ${ }^{105}$

Since inscriptions were not found in the Chapelle Carton, only the several terracottas retrieved allow the identification of the deities worshipped in this temple. Recently, Lorenzo Mancini, ${ }^{106}$ resuming and substantiating the hypotheses of C. Picard ${ }^{107}$ and Paolo Xella, ${ }^{108}$ attributed this building to Baal Hammon and Tinnit-Caelestis. Because of its remarkable size (h. $51 \mathrm{~cm})$, the mask found there could be included among the shrine simulacra rather than among the ex voto.

In both these contexts (the Tophet of Motya and the Chapelle Carton), the only standard feature is represented by the god Baal Hammon, along with the references to the goddess Tinnit ${ }^{109}$ recognizable also in several symbols. Some of them (the Sign of Tanit, the rosette and the crossed disc) - as already noted ${ }^{110}$ - were found together in the mosaic decoration of the domestic shrine discovered at Carthage in the Ben Ayed plot (Phase VI: c. 425 BC). ${ }^{111}$

Considering all these data, two hypotheses can be proposed for this group of masks: a) it could be a (divine?) character - without epigraphic evidence - linked to the circle of Baal Hammon or b) it could be identified with a peculiar facet of the same god, perhaps connected to a specific ritual.

A hairless male protome retrieved in the Tophet of Motya (fig. 5) and interpreted according to Antonia Ciasca ${ }^{112}$ - as a simulacrum of Baal Hammon, ${ }^{113}$ testifies to the

104 Amadasi Guzzo - Zamora López 2014, 162. However, in the Tophet of Motya, only votive protomes and terracottas testified to the presence of a female deity. Apparently, the introduction of the cult of Tinnit in the small Sicilian island did not forerun the $4^{\text {th }}$ century BC.

105 For a list of these cases, see: Amadasi Guzzo 2008

106 Mancini 2012, 63-65.

107 Picard 1965-1966, 90

108 Xella 1991, 123, 135.

109 Picard 1965-1966, 90. Recently, on these two divine characters, see: Garbati 2014.

110 Fariselli 2011, 166

111 Hvidiberg-Hansen 2007. Among the sacred contexts, we can include also the archive retrieved by Friedrich Rakob at Carthage. It comprehended 4762 cretulae, some of which representing grinning masks (Berger 1997, 142, nos. 394-397, pl. 73).

112 Ciasca $1991,30-31 ; 1992,149$. This is the only deity epigraphically attested in the Tophet at Motya.

113 Nigro 2004, 39, fig. 3. 
presence of iconographies different from the one that became canonical ${ }^{114}$ around the $3^{\text {rd }}$ century BC: the bearded standing or, more often, the enthroned character. ${ }^{115}$

This observation especially could support the latter hypothesis, which also explains (some of) the transformations and anomalies observed in the development of the grinning masks. The changes occurring during phase II, when references to a female deity appeared, echo the Tophet inscriptions, namely the later addition of the goddess Tinnit. The epithet "face of Baal" attributed to this goddess takes on interesting meaning when there are female symbols on the face of a male character perhaps recognizable as Baal Hammon. Moreover, the reference to Tinnit of these motifs could explain their absence in the grinning mask from the Tophet of Motya, where this goddess seems to appear only in the $4^{\text {th }}$ century BC. Furthermore, there is perhaps a direct visual connection between the oversized ears of some phase II masks, their possible interpretation and the final formula - "indeed [the god] has heard the voice of his words" - of some Tophet inscriptions, approximately contemporaneous (c. $6^{\text {th }}-5^{\text {th }}$ centuries BC). ${ }^{116}$

In any case, these proposals should be checked in light of future discoveries, also adding a religious and historical perspective to those adopted in this study.

\section{REFERENCES}

Acquaro, E. - De Vita, P.

$2010 \quad$ I Fenici. Storia e tesori di un'antica civiltà, Vercelli 2010.

Almagro Gorbea, M.J.

$1980 \quad$ Corpus de las terracottas de Ibiza (Bibliotheca praehistorica Hispana 18), Madrid 1980.

Amadasi GuZzo, M.G.

2008 Su due dediche da Henchir Ghayadha: Vicino Oriente 14 (2008), pp. 249-255.

AMADASI GUZZO, M.G. - ZAMORA LÓPEZ, J.Á.

2014 The Epigraphy of the Tophet: P. Xella (ed.), The Tophet in the Phoenician Mediterranean (Studi Epigrafici e Linguistici sul Vicino Oriente Antico 29-30), Verona 2014, pp. 159-192.

BARNETT, R.D.

1960 Some Contacts between Greek and Oriental Religions: Éléments orientaux dans la religion grecque ancienne. Colloque de Strasbourg, 22-24 mai 1958 (Bibliothèque des Centres d'Études supérieures spécialisés. Travaux du Centre d'Études supérieures spécialisé d'histoire des religions de Strasbourg), Paris 1960, pp. 143-153.

BARNETT, R.D. - MENDLESON, C. (eds.)

1987 Tharros. A Catalogue of material in the British Museum from Phoenician and Other Tombs at Tharros, Sardinia, London 1987.

BARTOLONI, P.

1967 La necropoli di S. Sperate: M.G. AMADASI - F. BARRECA - P. BARTOLONI - M. FANTAR - D. FANTAR - S. MOSCATI, Monte Sirai - IV. Rapporto preliminare della Missione archeologica dell'Università di Roma e della Soprintendenza alle Antichità di Cagliari (Studi Semitici 25), Roma 1967, pp. 127-143.

114 Niehr 2008

115 Xella 1991, 106-140.

116 Amadasi Guzzo - Zamora López 2014, 175-176. 
XVIII (2014) Listen and protect: reconsidering the grinning masks after a recent find from Motya

1973 Gli amuleti punici del tofet di Sulcis: Rivista di Studi Fenici 1 (1973), pp. 181-203.

BENICHOU-SAFAR, $\mathrm{H}$.

1982 Les tombes puniques de Carthage: topographie, structures, inscriptions et rites funéraires (Études d'antiquités africaines), Paris 1982.

2004 Le tophet de Salammbô à Carthage. Essai de reconstitution (Collection de l'Ecole française de Rome 342), Paris 2004.

BEN-TOR, A.

2006 The Sad Fate of Statues and the Mutilated Statues of Hazor: S. Gitin - J. E. WRighT - J. P. DESSEL (eds.), Confronting the past: archaeological and historical essays on ancient Israel in honor of William G. Dever, Winona Lake 2006, pp. 3-16. BERGER, D.

1997 Die Tonsiegel aus dem Karthagischen Tempelarchiv: F. RAKOB (ed.), Die deutschen Ausgrabungen in Karthago (Karthago II), Mainz 1997, pp. 10-214.

BERNABÒ BREA, L.

$1981 \quad$ Menandro e il teatro greco nelle terracotte liparesi, Genova 1981.

BERNARDINI, P.

2005 Recenti scoperte nella necropoli punica di Sulcis: Rivista di Studi Fenici 33 (2005) [2007], pp. 63-80.

BIKAI, P.M.

1978 The Pottery of Tyre, Warminster 1978.

BISI, A.M.

1988 Terracotta figures: S. Moscati (ed.), The Phoenicians. Catalogue of the Exhibition in Palazzo Grassi, Venice, 6th March - 6 November 1988, Milan 1988, pp. 328-353.

Black, J. - Green, A.

1992 Gods, Demons and Symbols of Ancient Mesopotamia: An Illustrated Dictionary, London 1992.

BONNET, C.

1988 Melqart: cultes et mythes de l'Héraclès tyrien en Méditerranée (Studia Phoenicia VIII), Leuven 1988

\section{CAmpanella, L.}

2008 Il cibo nel mondo fenicio e punico d'Occidente. Un'indagine sulle abitudini alimentari attraverso l'analisi di un deposito urbano di Sulky in Sardegna (Collezione di Studi Fenici 43), Pisa - Roma 2008.

2009 Matrici fittili, coroplastica e altri materiali: J. BonETTO - G. FALEZZA - A.R. GHIOTTO (a cura di), Nora. Il Foro Romano. Storia di un'area urbana dall'età fenicia alla tarda antichità (1997-2006), II.1. I materiali preromani (Scavi di Nora I), Padova 2009, pp. $525-538$.

CARTON, L.

1929 Sanctuaire punique découvert à Carthage, Paris 1929.

CHIARENZA, N.

2013 On Oriental Persistence in the Hellenistic Town of Soluntum: a New Hypothesis about the Statue of an Enthroned Goddess: L. BOMBARDIERI - A. D'AGOSTINO - G. GUARDUCCI - V. ORSI - S. VALENTINI (eds.), SOMA 2012 Identity and Connectivity: Proceedings of the 16th Symposium on Mediterranean Archaeology, Florence, Italy, 1-3 March 2012 (British Archaeological Reports - International Series 2581), Oxford 2013, pp. 945-954.

CIASCA, A.

1964 III. Le terrecotte: A. Ciasca - M. Forte - G. Garbini - S. Moscati - B. Pugliese - V. TuSA, Mozia - I. Rapporto preliminare della Missione archeologica della Soprintendenza 
alle Antichità della Sicilia Occidentale e dell'Università di Roma (Studi Semitici 12), Roma 1964, pp. 61-69.

1988 Masks and protomes: S. Moscati (ed.), The Phoenicians. Catalogue of the Exhibition in Palazzo Grassi, Venice, 6th March - 6 November 1988, Milan 1988, pp. 354-369.

1991 Protomi e maschere puniche (Itinerari fenici e punici VII. Comitato nazionale per gli studi e le ricerche sulla civiltà fenicia e punica), Roma 1991.

1992 Mozia: sguardo d'insieme sul tofet: Vicino Oriente 8 (1992), pp. 113-155.

CIASCA, A. - TOTI, M.P.

$1994 \quad$ Scavi a Mozia. Le terrecotte figurate (Collezione di Studi Fenici 33), Roma 1994.

CINTAS, P.

1946 Amulettes puniques (Publications de l'Institut des hautes études de Tunis I), Tunis 1946.

CORNELIUS, I.

1994 The Iconography of the Canaanite Gods Reshef and Ba'al: Late Bronze and Iron Age I

Culican, W. Periods (c 1500-1000 BCE) (Orbis Biblicus et Orientalis 140), Fribourg 1994.

1975-1976 Some Phoenician Masks and Other Terracottas: Berytus 24 (1975-1976), pp. 47-87.

1976 Phoenician demons: Journal of Near Eastern Studies 35 (1976), pp. 21-24.

DAYAGI-MENDELS, M.

2002 The Akhziv cemeteries: the Ben-Dor excavations, 1941-1944 (Israel Antiquities Authority Reports 15), Jerusalem 2002.

Del VAis, C.

1993 La simbologia astrale delle stele votive di Mozia. Osservazioni preliminari: Sicilia Archeologica 81 (1993), pp. 51-73.

Del VAis, C. - FARISELli, A.

2012 Le maschere nella Sardegna punica: contesti, modelli e valore iconologico: H. MELLER R. MARASZeK (Hrsg.), Masken der Vorzeit in Europa, II. Internationale Tagung vom 19. bis 21. November 2010 in Halle (Saale); Landesamt für Denkmalpflege und Archäologie Sachsen-Anhalt, Landesmuseum für Vorgeschichte (Tagungen des Landesmuseums für Vorgeschichte Halle 7), Halle 2012, pp. 71-79.

Di MAURO, D. - Alfonsi, L. - SAPIA, V. - URBini, S.

2014 A neighborhood revealed by geophysical prospection: An example of urbanization at the Phoenician-Punic settlement of Mozia (western Sicily, Italy): Journal of Applied Geophysics 104 (2014), pp. 114-120.

EKMAN, P.

2003 Emotions Revealed. Recognizing faces and feelings to improve communication and emotional life (Times Books), New York 2003.

FACENNA, D.

1996 Alcuni segni facciali nel Medio e Vicino Oriente: E. ACQUARO (a cura di), Alle soglie della classicità: il Mediterraneo tra tradizione e innovazione. Studi in onore di Sabatino FANTAR, M.H. Moscati, Roma 1996, pp. 695-706.

1996 Le signe dit de Tanit au Cap Bon: E. ACQUARo (a cura di), Alle soglie della classicità: il Mediterraneo tra tradizione e innovazione. Studi in onore di Sabatino Moscati, Roma 1996, pp. 706-723.

FARISELLI, A.C

2011 Maschere puniche. Aggiornamenti e riletture iconologiche: Ocnus. Quaderni della Scuola di Specializzazione in Beni Archeologici 19 (2011), pp. 155-170. 
XVIII (2014) Listen and protect: reconsidering the grinning masks after a recent find from Motya

2012 Note di iconografia punica in Sardegna. Il triangolo apicato: C. Del VAIS (ed.), Epi oinopa ponton. Studi sul Mediterraneo antico in ricordo di Giovanni Tore, Oristano 2012, pp. 539-549.

2014 Maschere antropomorfe in terracotta nell'oriente fenicio: riflessioni per la redazione di un corpus: A. Lemaire (ed.) Phéniciens d'Orient et d'Occident. Mélanges Josette Elayi (Cahiers de l'Institut du Proche-Orient Ancien du Collège de France II), Paris 2014, pp. 147-167.

FERNÁNDEZ, J.H.

1992 Excavaciones en la necrópolis del Puig des Molins (Eivissa): las campañas de Carlos Román Ferrer, 1921-1929 (Trabajos del Museo Arqueológico de Ibiza 28-29), Ibiza 1992. GARBATI, G.

2014 Baal Hammon and Tinnit in Carthage: the Tophet between the Origin and the Expansion of the Colonial World: P. Xella (ed.), The Tophet in the Phoenician Mediterranean GARBINI, G. (Studi epigrafici e linguistici sul Vicino Oriente antico 29-30), Verona 2014, pp. 49-64.

1968 Maschere puniche: Annali dell'Istituto Universitario Orientale di Napoli 18 (1968), pp. 319-330.

1996 Palmira colonia fenicia: La parola del passato 51 (1996), pp. 81-94.

GAUCKLER, P.

$1915 \quad$ Nécropoles puniques de Carthage. Carnets de fouilles et études, Paris 1915.

GJerstad, E. - Lindros, J. - SJøQvist, E. - Westholm, A.

1935 The Swedish Cyprus Expedition. Finds and Results of the Excavations in Cyprus 1927-

GuBEL, E. 1931, vol. II, Stockholm 1935.

1985 Phoenician Lioness Heads from Nimrud: origin and function: E. GUBEL - E. LIPINSKI

HATZis, J. (eds.), Phoenicia and its Neighbours (Studia Phoenicia III), Leuven 1985, pp. 181-202.

2004 The wrinkle and its measurement. A skin surface Profilometric method: Micron 35 (2004), pp. 201-219.

HORN, F

2005 Les terres cuites d'origine orientale en péninsule Ibérique (VIII-VIe s. av. J.-C.): S. Celestino Perez - J. Jimenez Ávila (eds.), El periodo orientalizante: actas del III Simposio internacional de arqueología de Mérida: protohistoria del Mediterráneo occidental (Anejos de Archivo español de arqueología 35), Mérida 2005, pp. 1405-1415.

HUEHNERGARD, J. - LiEBOWITZ, H.

2013 The Biblical Prohibition Against Tattooing: Vetus Testamentum 63 (2013), pp. 59-77. HVIDIBERG-HANSEN, O.

2007 Die Embleme im Paviment: H.G. NiEMEYeR - R.F. Docter - K. SCHMidT - B. Bechtold, Karthago. Die Ergebnisse der Hamburger Grabung unter dem Decumanus Maximus KARAGEORGHIS, V. (Hamburger Forschungen zur Archäologie 2), Mainz am Rhein 2007, pp. 223-228.

1996 Anthropomorphic clay masks from Cyprus: E. ACQUARO (a cura di), Alle soglie della classicità: il Mediterraneo tra tradizione e innovazione: studi in onore di Sabatino Moscati, Roma 1996, pp. 813-821.

2006 Aspects of everyday life in ancient Cyprus: iconographic representations, Nicosia 2006.

KLETTER, R.

2007 To Cast an Image: Iron Age Masks from Judah and the Biblical 'Masekah: A. BEN ToR J.P. Dessel - W.G. Dever - A. Mazar - J. Aviram (eds.), "Up to the Gates of Ekron”. 
Essays on the archaeology and history of the Eastern Mediterranean in Honor of Seymour Gitin, Jerusalem 2007, pp. 189-208.

LAMBERT, W.G.

1987 Gilgamesh in literature and art. The second and first millennium: A.E. FARKAS - P.O. HARPER - E.B. HARRISON (eds.), Monsters and demons in the ancient and medieval worlds: papers presented in honor of Edith Porada, Mainz on Rhine 1987, pp. 37-52.

LANCEL, S.

1995 Carthage et les échanges culturels en Méditerranée: Carthage: l'histoire, sa trace et son écho. Catalogue de l'exposition, Paris, Musée du Petit Palais, 9 mars - 2 juillet 1995, Paris 1995, pp. 24-48.

LANCELLOTTI, M.G.

2006 Magia, pantheon, sacrificio: riflessioni metodologiche su alcuni temi di religione fenicia: J.-P. VITA - J.-A. ZAMORA (eds.), Nuevas perspectivas I: la investigación fenicia y púnica (Cuadernos de archeología mediterránea 13), Barcelona 2006, pp. 61-72.

2010 Dea Caelestis: studi e materiali per la storia di una divinità dell'Africa romana (Collezione di Studi Fenici 44), Roma 2010.

LIPIŃSKI, E.

1996 Egypto-Canaanite iconography of Reshef, Bàal, Horon, and Anat: Chronique d'Egypte 71 (1996), pp. 254-262.

LÓPEZ-BERTRAN, M. - GARCIA-VENTURA, A.

2008 Materializing music and sound in some Phoenician and Punic Contexts: Saguntum 40 (2008), pp. 27-36.

LUISELLI, M.M.

2013 Images of Personal Religion in Ancient Egypt: An Outline: M.M. LuISELLI - J. MoHN - S. GrIPENTRO (eds.), Kult und Bild Die bildliche Dimension des Kultes im Alten Orient, in MANCINI, L. der Antike und in der Neuzeit (Diskurs Religion 1), Würzburg 2013, pp. 13-40.

2012 L'architettura templare di Cartagine alla luce delle fonti letterarie e delle testimonianze materiali: Byrsa 17-18 (2010) [2012], pp. 39-72.

MARKOE, G.E.

1990 The emergence of Phoenician art: Bulletin of the American Schools of Oriental Research 279 (1990), pp. 13-26.

MOOREY, P.R.S.

2005 Ancient Near Eastern Terracottas with a catalogue of the collection in the Ashmolean

MORSTADT, B. Museum, Oxford 2005.

2010 Phönizische Masken - zwischen Abbild und Abschreckung: H. MELLER - R. MARASzeK (Hrsg.), Masken der Vorzeit in Europa, I. Internationale Tagung vom 20. bis 22. November 2009 in Halle (Saale), Landesamt für Denkmalpflege und Archäologie Sachsen-Anhalt, Landesmuseum für Vorgeschichte (Tagungen des Landesmuseums für Vorgeschichte Halle 4), Halle 2010, pp. 203-223.

Moscati, S.

1968 I Fenici in Sardegna, Milano 1968.

1983 Sileno. Dalla maschera al pendente: Rendiconti dell'Accademia Nazionale dei Lincei 38 (1983), pp. 271-273.

1987 Le officine di Tharros (Studia Punica 2), Roma 1987.

$1990 \quad$ L'arte dei Fenici, Milano 1990.

1996 La bottega del mercante: artigianato e commercio fenicio lungo le sponde del Mediterraneo, Torino 1996. 
XVIII (2014) Listen and protect: reconsidering the grinning masks after a recent find from Motya

NIEHR, H

2008 Baal Hammon: Iconography of Deities and Demons: Electronic Pre-Publication, http://www.religionswissenschaft.uzh.ch/idd/prepublications/e_idd_baal_hammon.pdf, (2008), pp. 1-3

NiEMEYER, H.G.

2007 Figürliche Terrakotten: H.G. NiEMEYeR - R.F. Docter - K. SchmidT - B. Bechtold, Karthago. Die Ergebnisse der Hamburger Grabung unter dem Decumanus Maximus (Hamburger Forschungen zur Archäologie 2), Mainz am Rhein 2007, pp. 758-764.

Niemitz, C. - NibBrig, M. - ZACHER, V.

2007 Human ears grow throughout the entire lifetime according to complicated and sexually dimorphic patterns. Conclusions from a cross-sectional analysis: Anthropologischer Anzeiger 65 (2007), pp. 391-413.

NigRO, L.

2004 Il tofet: L. Nigro - G. Rossoni (a cura di), «La Sapienza» a Mozia. Quarant'anni di ricerca archeologica, 1964-2004. Catalogo della Mostra, Università di Roma "La Sapienza", Facoltà di Scienze Umanistiche, Museo dell'Arte Classica, 27 febbraio-18 maggio 2004, Roma 2004, pp. 38-45.

2004-2005 Un pithos dipinto dalla fortezza occidentale di Mozia: Scienze dell'Antichità 12 (20042005), pp. 727-737.

2013 Mozia: il Tofet e la città. Il limite meridionale del santuario e le strutture ad esso collegate negli scavi della Sapienza 2010-2011: Scienze dell'Antichità 19 (2013), pp. 37-53.

O’NEILL, J.P. (ed.)

1986 Treasures of the Holy Land: ancient art form the Israel Museum, NY. Exhibition ORSINGHER, A. catalogue, The Metropolitan Museum of Art, New York 1986.

2007 Bruciaprofumi lotiformi: una produzione fenicia: Vicino Oriente 13 (2007), pp. 115-140.

2013 The Hellenization of the Punic World: a view from the Tophet: L. BOMBARDIERI - A D’Agostino - G. GuARDUCCI - V. ORSI - S. VALENTINI (eds.), SOMA 2012 Identity and Connectivity: Proceedings of the 16th Symposium on Mediterranean Archaeology, Florence, Italy, 1-3 March 2012 (British Archaeological Reports - International Series 2581), Oxford 2013, pp. 693-701.

Peters, S. (ed.)

2004 Hannibal ad portas: Macht und Reichtum Karthagos. Herausgegeben vom Badischen Landesmuseum Karlsruhe. Begleitbuch zur Großen Sonderausstellung, 26.09.2004 30.01.2005, Stuttgart 2004.

PICARD, C.

1965-1966 Sacra punica. Étude sur les masques et rasoirs de Carthage: Karthago 13 (1965-1966), pp. 3-115.

1976 Les représentation de sacrifice molk sur les ex-voto (stéles) de Carthage: Karthago 17 (1975-1976) [1976], pp. 67-138.

1978 Les représentation de sacrifice molk sur les ex-voto (stéles) de Carthage: Karthago 18 (1975-1976) [1978], pp. 5-116.

PIZZIMENTI, S

2014 The Astral Family in Kassite Kudurrus Reliefs Iconographical and Iconological Study of Sîn, Šamaš and Ištar Astral Representations: L. MARTI (ed.), La famille dans le ProcheOrient ancien: réalités, symbolismes, et images. Proceedings of the $55^{\text {th }}$ Rencontre Assyriologique Internationale at Paris 6-9 July 2009, Winona Lake 2014, pp. 151-161. 
POINSSOT, L. - LANTIER, R.

1926 Un bandeau de front punique: Comptes rendus de l'Académie des Inscriptions et BellesLettres 70 (1926), pp. 6-8.

QUILLARD, B.

1987 Bijoux carthaginois, II. Porte-amulettes, sceaux-pendentifs, pendants, boucles, anneaux et bagues d'après les collections du Musée national du Bardo et du Musée national de Carthage (Publications d'histoire de l'art et d'archéologie de l'Université catholique de Louvain XXXII 3), Louvain-la-Neuve 1987.

RIBICHINI, S.

2003 Il riso sardonico. Storia di un proverbio antico, Sassari 2003.

RODERO RIAZA, A.

1991 Protohistoria y Colonizaciones: Museo Arqueológico Nacional. Guía General, I, Madrid 1991, pp. 49-87.

ROMÁN FERRER, C.

1923 Excavaciones en Ibiza: memoria de los resultados obtenidos en las excavaciones Rose, $\mathrm{H}$. practicadas en 1922 (Junta Superior de Excavaciones y Antigüedades 58), Madrid 1923.

2006 Die römischen Terrakottamasken in den Nordwestprovinzen (Monumenta artis Romanae 37), Wiesbaden 2006.

SADER, $\mathrm{H}$.

2005 Iron Age Funerary Stelae from Lebanon (Cuadernos de archeología mediterránea 11), Barcelona 2005.

SMITH, J.S.

2009 Art and society in Cyprus from the Bronze Age into the Iron Age, Oxford - New York 2009.

SмITH, S.

1924 The face of Humbaba: Liverpool Annals of Archaeology and Anthropology 11 (1924), pp. $105-114$.

SPANU, P. - ZuCCA, R.

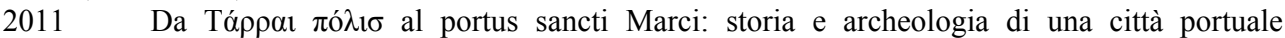
dall'antichità al Medioevo: A. Mastino - P. G. Spanu - A. Usai - R. ZucCA (eds.), Tharros Felix 4, Roma 2011, pp. 15-103.

STERN, E.

1976 Phoenician Masks and Pendants: Palestine Exploration Quarterly 108 (1976), pp. 109118 .

2010 Excavations at Dor: figurines, cult objects and amulets: 1980-2000 seasons, Jerusalem 2010.

Steymans, H.U. (ed.)

2010 Gilgamesh: epic and iconography (Orbis Biblicus et Orientalis 245) Fribourg 2010.

TARAMELLI, A.

1918 Cabras - Maschere fittili apotropaiche della necropoli punica di Tharros, ed altra pure apotropaica della necropoli di S. Sperate: Notizie degli Scavi di Antichità 15 (1918), pp. $145-155$.

TRONCHETTI, C.

1986 Tomba punico-romana a S. Sperate (Cagliari): Studi Sardi 26 (1981-1985) [1986], pp. $101-111$.

UGAS, G.

1993 San Sperate dalle origini ai baroni (Norax 2), Cagliari 1993. 
XVIII (2014) Listen and protect: reconsidering the grinning masks after a recent find from Motya

Vermeule, C. (ed.)

1972 Art of ancient Cyprus. Catalogue of the collections, Museum of Fine Arts, Boston, Boston 1972.

Yadin, Y. - Aharoni, Y. - Amiran, R. - Dothan, T. - Dothan, M. - Dunayevisky, I. - Perrot, J.

1961 Hazor III-IV. The James A. de Rothschild Expedition at Hazor. An Account of the Third and Fourth Seasons of Excavation, 1957-1958, Jerusalem 1961.

WIEDERKEHR SCHULER, E.

2004 Les protomés féminines du sanctuaire de la Malophoros à Sélinonte (Cahiers du Centre Jean Bérard 22), Naples 2004.

Xella, $\mathrm{P}$.

1991 Baal Hammon. Recherches sur l'identité et l'histoire d'un dieu phénico-punique (Collezione di Studi Fenici 32), Roma 1991.

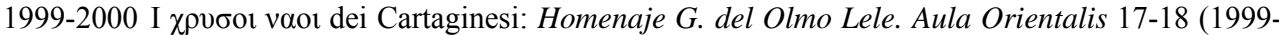
2000), pp. 363-366.

ZuCCA, R.

2012 La maschera ghignante da Tharros dell'Antiquarium Arborense di Oristano: C. DeL VAIS (ed.), Epi oinopa ponton: studi sul Mediterraneo antico in ricordo di Giovanni Tore, Oristano 2012, pp. 473-481. 


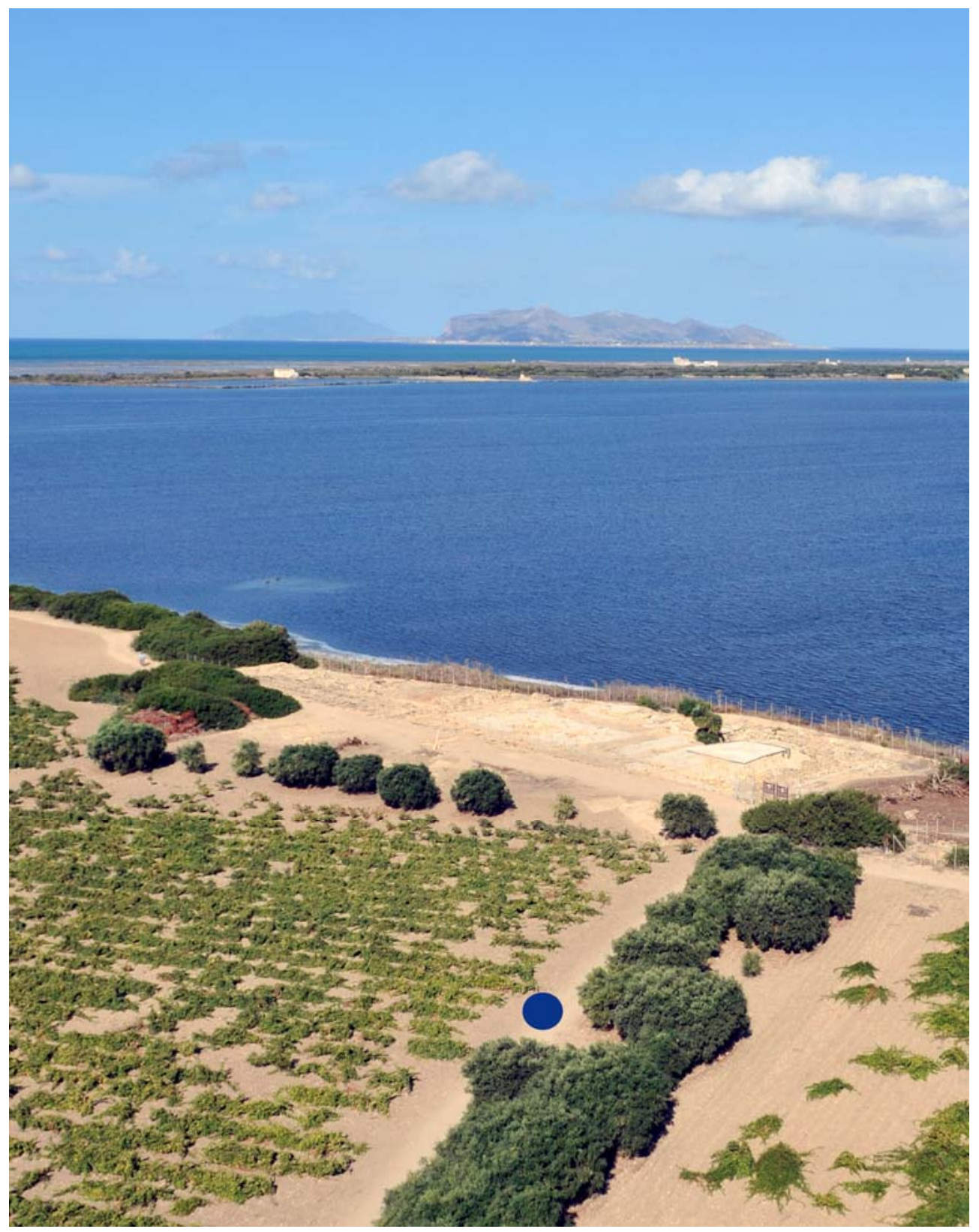

Fig. 1 - Motya, Tophet: aerial view of the finding spot (circle), from the south-east (courtesy of Rome «La Sapienza» Archaeological Expedition to Motya - Prof L. Nigro). 

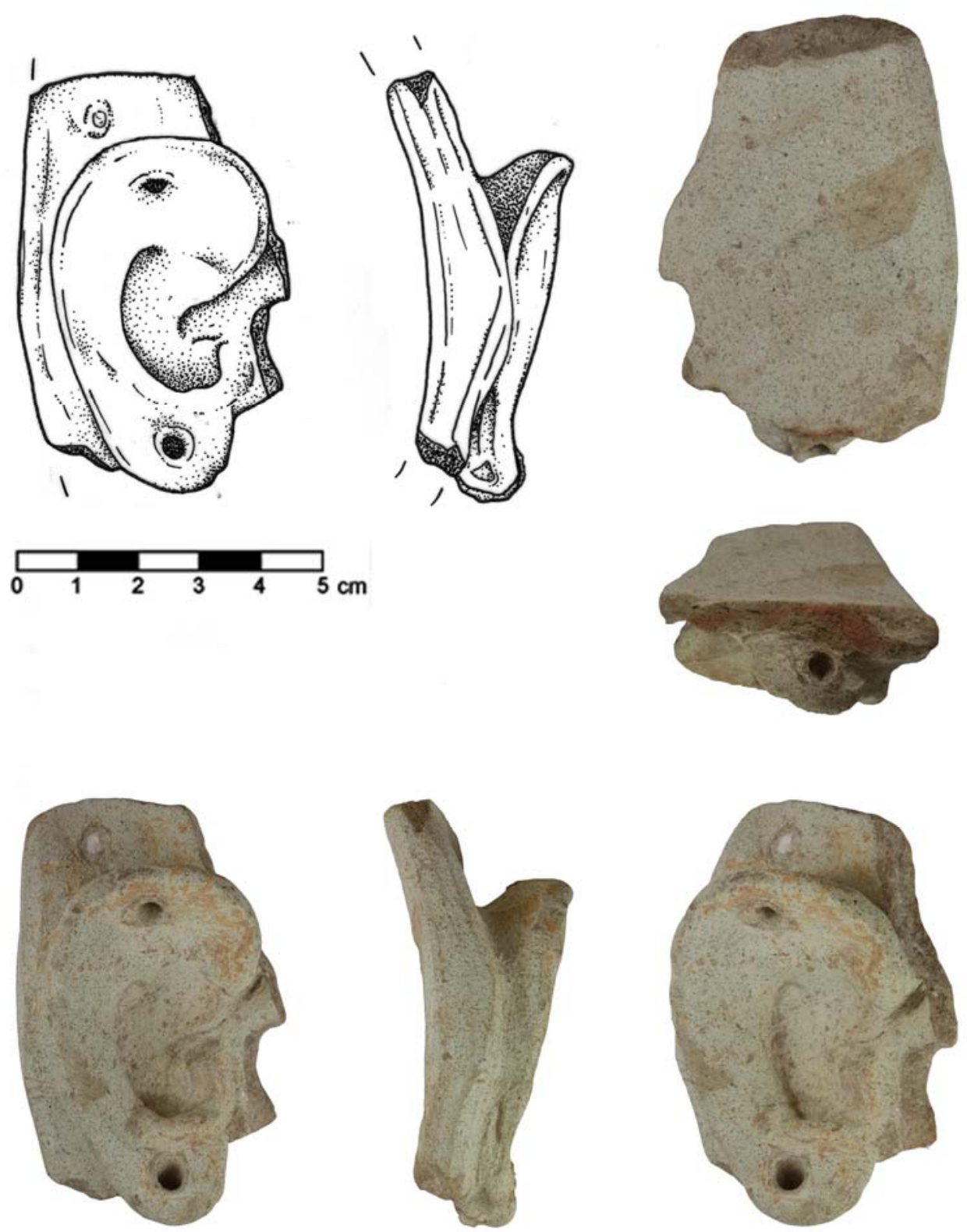

Fig. 2 - Motya: fragmentary mask or protome, G. Whitaker Museum, inv. no. 8071 (drawing by A. Guari and photos by the Author). 
Fig. 3 - Chrono-typological sequence of the grimacing mask:

1, Carthage, necropolis: tomb 30. Musée du Louvre, Paris, Département des Antiquités orientales, inv. no. AO $3242 . \mathrm{H} .19 \mathrm{~cm}, \mathrm{~L} .16 \mathrm{~cm}$ (photo (C) RMNGrand Palais [musée du Louvre] - Christophe Chavan);

2, Carthage, necropolis: tomb 1. Musée National du Carthage, Tunis, inv. no. unkn. H. 13 cm, L. 12 cm, D. 3.5 cm (after Moscati 1996, pl. 22);

3, Carthage, necropolis. Musée National du Bardo, Tunis, inv. no. unkn. H. $17 \mathrm{~cm}$;

4, Tharros, necropolis. Museo Nazionale "G.A. Sanna", Sassari, inv. no. 2652. H. $17.5 \mathrm{~cm}$, L. $6.5 \mathrm{~cm}$ (after Moscati 1996, 125);

5, Tharros, necropolis/tophet. Antiquarium Arborense, Oristano, Efisio Pischedda Collection, inv. no. P.301. H. 19.2 cm, L. $14.1 \mathrm{~cm}$ (after Moscati 1990, 125);

6, Motya, Tophet: middle favissa. G. Whitaker Museum, Marsala, inv. no. 2387; MT64/2723. H. 20 cm, L. 15 cm (after Moscati 1996, 124);

7, Tharros, necropolis: tomb 7. British Museum, London, inv. no. ME 133128, AN32498001. H. $17.7 \mathrm{~cm}$ (Courtesy of the Trustees of the British Museum);

8, San Sperate, necropolis. Museo Archeologico Nazionale, Cagliari, inv. no. 20849. H. 18 cm (Peters 2004, 165-166, no. 49);

9, Sinis di San Vero Milis. Lost. Dimensions: unavailable (after Spanu - Zucca 2011, 53, note 289, fig. 29, right);

10, Carthage, necropolis. Musée National du Bardo, Tunis, inv. no. unkn. H. 14 cm, L. 13 cm, D. $10 \mathrm{~cm}$ (after Lancel 1995, 45);

11, Carthage, necropolis. Musée National du Bardo, Tunis, inv. no. unkn. H. $17 \mathrm{~cm}$, L. 15 cm, D. 8 cm (after Lancel 1995, 44);

12, Puig des Molins, necropolis. Museo Arqueológico Nacional, Madrid, inv. no. MAN 1923/60/256. H. 13 cm, L. 9 cm, D. 7 cm (after Rodero Riaza 1991, 73, 75 , fig. 15);

13, Tharros, necropolis. Museo Archeologico Nazionale, Cagliari, inv. no. unkn. H. $19 \mathrm{~cm}$, L. $15 \mathrm{~cm}$ (after Moscati 1990, 84);

14, Puig des Molins, necropolis. Museu d'Arqueologia de Catalunya, Barcelona, inv. no. MAC 8600. H. $13.5 \mathrm{~cm}$, L. $11 \mathrm{~cm}$ (after Moscati 1990, 220);

15, Puig des Molins, necropolis: Hypogeum 22. Museu Arqueològic d'Eivissa i Formentera, Eivissa, inv. no. MAE 3904. H. $12 \mathrm{~cm}$ (Courtesy of the Museu Arqueològic d'Eivissa i Formentera);

16, Carthage: Chapelle Carton. Musée National du Carthage, Tunis, inv. no. unkn. H. 50 cm, L. 41 cm, D. 17 cm (after Lancel 1995, 25). 
XVIII (2014) Listen and protect: reconsidering the grinning masks after a recent find from Motya

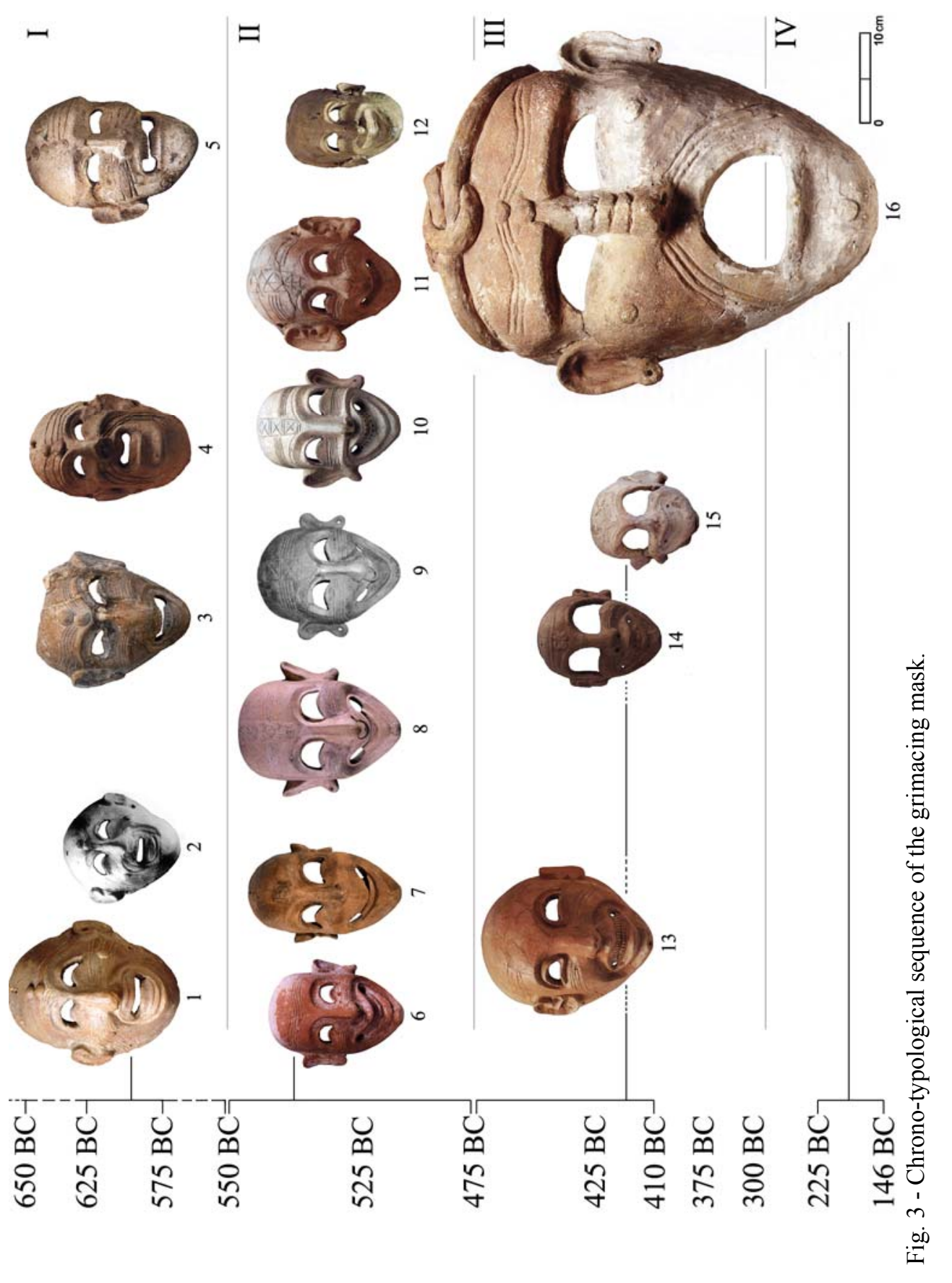




\begin{tabular}{|c|c|c|c|c|c|c|c|c|c|c|}
\hline \multirow{2}{*}{ 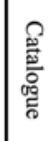 } & \multirow[t]{2}{*}{ CHIN } & \multicolumn{2}{|c|}{ JAW } & \multicolumn{2}{|c|}{ CHEEKBONE } & \multicolumn{4}{|c|}{ FOREHEAD } & \multirow{2}{*}{ 흠 } \\
\hline & & $\bar{\Phi}$ & 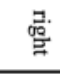 & $\bar{\Phi}$ & 善 & $\bar{g}$ & $\begin{array}{l}\frac{\mathrm{g}}{\mathrm{z}} \\
\frac{\mathrm{z}}{\mathrm{c}}\end{array}$ & 营 & $\overrightarrow{\mathrm{s}}$ & \\
\hline - & & & & $\bigcirc$ & $\bigcirc$ & & $\bigcirc \bigcirc$ & & & \\
\hline N & & & & $\bigcirc$ & $\bigcirc$ & & $\bigcirc \bigcirc$ & & & \\
\hline$\omega$ & & & & & & & $\bigcirc \bigcirc$ & & & - \\
\hline$\rightarrow$ & & & & & & & $\bigcirc \bigcirc$ & & & \\
\hline u & & $\otimes$ & $\otimes$ & & & $\otimes$ & 0000 & $\otimes$ & & \\
\hline$a$ & & & & & & & & & & \\
\hline$\checkmark$ & & & & & & & 可 & & & \\
\hline$\infty$ & 龆 & & & & & & 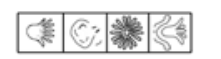 & & & \\
\hline 0 & $\bowtie$ & & & & & & 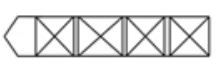 & & & $=$ \\
\hline б & & & & & & & 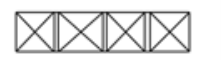 & & & \\
\hline$=$ & & & & & & & $\triangleleft \otimes \infty \Delta$ & & & \\
\hline $\bar{N}$ & & & & & & & $\frac{000000000000}{000000000000}$ & & & \\
\hline $\bar{\omega}$ & & & & & & & (3) & & $\hat{p}$ & \\
\hline F & $\mathscr{B}$ & & & & & & 98 & & & $\exists$ \\
\hline$\vec{n}$ & & & & & & & & & & \\
\hline $\bar{\sigma}$ & $\bigcirc$ & & & $\bigcirc$ & 0 & & $\bigcirc$ & & & ¿ \\
\hline
\end{tabular}

Fig. 4 - Chrono-typological sequence of the symbols on the grimacing masks. 


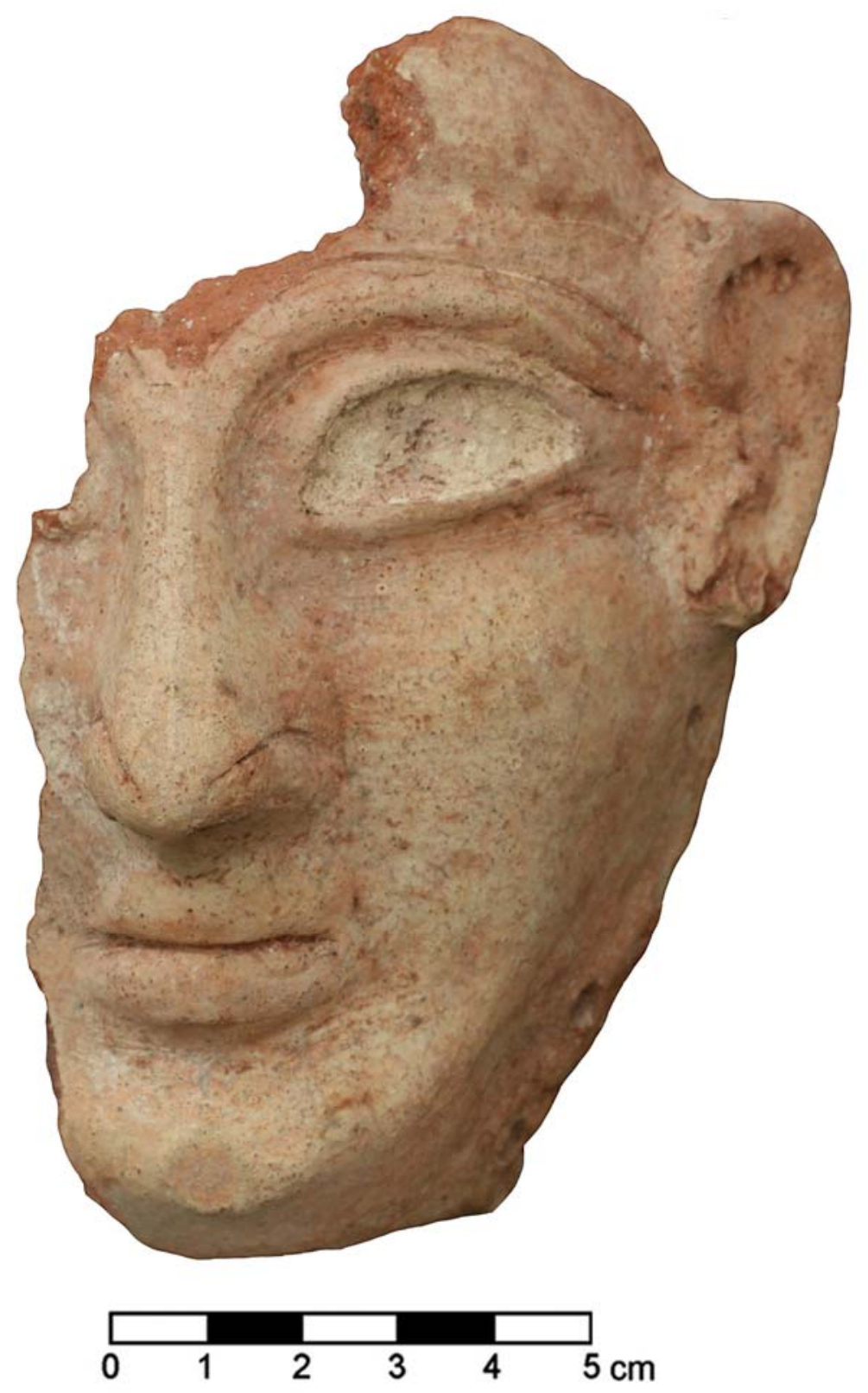

Fig. 5 - Motya, Tophet: male protome MT67/387, c. $5^{\text {th }}$ century BC. G. Whitaker Museum, Marsala, inv. no. 2420 (photo by the Author; courtesy of the G. Whitaker Museum). 